\title{
Judge Shigeru Oda: A Tribute to an International Treasure
}

\author{
MICHAEL REISMAN*
}

\begin{abstract}
According to classical legal positivism, the prerequisite to being selected as a judge on the International Court of Justice is legal expertise and high moral character - the personality of the judge is therefore merely the subject of idle curiosity. American Legal Realists understood that one could not explain past decisions or predict future decisions merely by extrapolating rules; account needed to be taken of history, culture, politics, economics, and the personality of the judge. As a person, Judge Oda is famous for his self-control in personal comportment. As a judge he is a study in independence, having produced an unmatched number of dissents and separate opinions. His contribution to international law will continue to influence us.
\end{abstract}

\section{Key words}

Judge Shigeru Oda; International Court of Justice; Japan

\section{INTRODUCTION}

National treasures are placed reverently in museums, a practice which celebrates the object of creativity rather than the creator and his living genius. In I955, however, the Japanese government, recognizing a need to commemorate the creator, designated the artists Tomimoto Kenkichi, Ishiguro Munemaru, Hamada Shoji, and Arakawa Toyozo as 'Living National Treasures'. Were the international legal community to follow suit, one of the first to be so designated would be Judge Shigeru Oda. He is, indeed, a living international treasure. As such, it is proper and entirely fitting for the Leiden Journal of International Law to take the occasion of his retirement from the bench of the International Court of Justice (ICJ) to reflect, not simply upon his immense production as scholar - I 8 books - and as a judge - a larger oeuvre than anyone who has sat on the ICJ or its predecessor - but also upon the man - the living treasure.

The unique drama of each of our lives is indispensable to understanding ourselves and what we do. No drama is richer or more important than any other, but some prove more influential than others. This is especially so if, following a traumatic internal struggle - one thinks of Leonardo, Luther, and Gandhi - we go on to discharge roles that project and amplify our inner lives so that they embrace many others in our community and, eventually, in other communities.

Myres S. McDougal Professor of International Law, Yale Law School. This article was originally prepared for delivery at the Program for Presentation to His Excellency Shigeru Oda, Judge at the International Court of Justice, of the Festschrift in his Honor, I6 March 2002, at the Max Planck Institute for Comparative Public Law and International Law, Heidelberg, Germany. 
The importance of the inner drama of each life is not limited to those who serve as our spiritual or political leaders. We are all important, but our judges are distinctive and special. For they are empowered to issue binding decisions that confirm, adapt, or rework the basic values of society, the values at stake in what Karl Llewellyn called the great 'trouble cases' of each era. The artist may touch, sometimes change those who choose to be his audience. The judge affects the normative structure of the world in which we live, the structure upon which we rely and with which we contend daily, the structure that shapes us and our actions. In this sense, we all find ourselves ineluctably members of the audience in each great judge's theatre.

If personality is one factor accounting for what each of us does, the personality of the judge in his or her judicial role may be of substantial and immediate importance. Because of the way in which judges work, an inquiry into their personalities is, in some ways, easier than a similar inquiry into those of other decision makers. Every decision maker leaves material that can be studied, but judges, particularly dissenting or concurring judges, leave a distinctive record, a written corpus in which the evidence of how he or she reacted to events and then rationalized and incorporated those reactions can be examined in terms of the forces that worked on and in their personalities. Studying that material can help the student better explain how decisions are made, how law evolves and how and why the judge conceived of himor herself and the judicial function.

The conception of a living national treasure assumes that the real miracle is not the object created, but the creator and his unique creative process. In a parallel fashion, any inquiry into the personality of a judge presupposes certain important jurisprudential assumptions. In classical positivism, law is a body of rules and judges are technicians. Consistent with this jurisprudential frame, the prerequisites to being selected as a judge on the ICJ are, according to Article 2 of the Statute of the ICJ, only legal expertise and high moral character. Lapses in moral character may be investigated. Beyond that, the personality of the judge is no more than the subject of idle curiosity. Since the judge is not considered central in shaping the law, and information about the judge's personality is not supposed to be useful for the predictive or explanatory tasks of the practitioner or legal scholar, why study it?

American Legal Realists, effecting a paradigm shift in jurisprudence as radical as Copernicus's in astronomy, provided a ready answer to this question. Oliver Wendell Holmes spoke to the practising North American lawyer when he said that the practice of law is nothing more pretentious than the prediction of what courts will, in fact, do. The Legal Realists understood that one could not explain past decisions or predict future decisions merely by extrapolating rules, no matter how rigorously logical one tried to be. Explaining why past decisions had been made the way they were and predicting how future decisions might be made required the observer, or practitioner, as the case might be, to take account of history, culture, current politics, economics, and, in particular, the personality of the judge. The judges of United States domestic law were moved centre stage; the rules were moved to the wings and the 'who' of the legal process along with its 'what' became a legitimate - and professionally useful focus of scholarship. 
In contrast to the situation in the United States where, from the earliest days of the republic, judicial decision has been fundamental and central to the political experience, judicial decision was long a marginal part of the international political system. Thus, although serious and searching biographies have been written of critical international political personalities, there has been, until Professor McWhinney's studies, no comparable biographical interest in the lives of international judges. Prior to the formation of the Permanent Court of International Justice (PCI), adjudications were carried out only by consent of the states concerned. The issues submitted were carefully circumscribed, as were, often, the principles of law to be applied. This left little room for judicial creativity, and creativity was hardly invited. In addition, the persons selected to decide the issues operated ad hoc so that, outside claims commissions, few international lawyers could expect to decide more than one or two cases in their careers. The result was that, when it came to individual judges, there was neither a jurisprudential 'who' nor a 'what' worth studying.

While the formation of the PCIJ had created new possibilities for the 'who' and 'what,' another, more troubling, obstacle arose virtually contemporaneously with the creation of the ICJ, keeping many of its judges from leaving any kind of personal stamp on the law. During the Cold War, totalitarian dictatorships contributed a significant number of judges to the ICJ. Unpleasant as it may be to observe, there is no reason to believe that the judges appointed to external arenas by those dictatorships were allowed to be any more independent than those appointed to internal arenas. Where judges, the myth of judicial independence notwithstanding, are subject to concealed, but effective political control, their personalities are not critical to understanding how the power process operates. Who remembers the names of Stalin's judges, let alone produces Festschriften for them?

\section{Personality}

Judge Oda is a particularly attractive subject for inquiry, since he may well have had the most dramatic inner life of any judge now on the Court, and his oeuvre is so distinctive that certain questions practically shoot out of it. Of course one wonders, as one would in the case of any intriguing judge, about Oda's parents, his class origins, his childhood, his adolescence, his faith and religious struggles, his relations to those closest to him in his family, and his culture. Happily, Professor McWhinney has supplied us with much of this material in the first of a series of biographies of judges of the ICJ that he is editing. But there is another critical question particular to Judge Oda's life: how he dealt with the collective trauma that ripped apart Japan during his formative years. For Judge Oda is a member of what the Japanese called the 'mid-war' generation, those who were shaped by the prewar political culture but came of age in the immediate postwar, with virtually all of their cultural preparation shattered - indeed atomized - into irrelevance.

As Judge Oda has mentioned to students he has addressed in the United States, he was a university student during the war and had been trained as a kamikaze pilot, the quintessential personal implementation of the war catechism, 'To match our 
training against their numbers and our flesh against their steel.' ${ }^{\text {I }}$ The young Oda was destined to die in a suicide attack and would have - if atomic bombs had not brought the war to an abrupt end.

One cannot help but wonder about the inner dynamics of a man whose life was saved by the weapon that destroyed so many of his countrymen and the memory of which continues to traumatize so many members of subsequent generations. What were the implications for Judge Oda of almost immediately entering the law faculty of a private university in the United States that was well-known for its influential contacts with the United States government? Judge Oda was the first Japanese student to come to the Yale Law School after the war. What did it mean to him to study there with Myres S. McDougal, a man who had held high posts in that government during the war, had supported the decision to drop the bombs, and, indeed, had led North America's international legal defense of postwar atmospheric testing of atomic and hydrogen bombs in the Pacific?

Kenzaburo Oë, the brilliant Japanese novelist who became an unofficial spokesman for the mid-war generation, relates a daily ritual that must have been a profound formative experience:

throughout the war, a part of each day in every Japanese school was devoted to a terrible litany. The Ethics teacher would call the boys to the front of the class and demand of them one by one what they would do if the Emperor commanded them to die. Shaking with fright, the child would answer: 'I would die, Sir, I would rip open my belly and die.' Students passed the imperial portrait with their eyes to the ground, afraid their eyeballs would explode if they looked His Imperial Majesty in the face. ${ }^{2}$

The empire collapsed. The emperor, a god-king and the linchpin of the world of the Japanese of that period, was revealed as an ordinary, fallible human being. Moreover, in a Confucian society in which the authority of superiors was to be unquestioned, the superiors were exposed as not simply fallible, but often wicked, sometimes criminal, and, above all, unworthy of trust. John Nathan, translator of Oë's remarkable novel, A Personal Matter, writes of the continuing, perhaps lifelong, consequences for a Japanese of that period of having been denied his 'ethical inheritance':

The values that regulated life in the world he knew as a child, however fatally, were blown to smithereens at the end of the war. The crater that remained is a gaping crater still, despite imported filler like Democracy.

To be sure, in this century much of this sort of trauma is not a uniquely Japanese phenomenon. It has recurred, mutatis mutandis, in other settings: for Germans in their ongoing and courageous Vergangenheitsbewaltigung, for those Roman Catholics for whom God has died, for communists listening to Khrushchev's exposure of Stalin's crimes and watching their empire crumble, and perhaps for Muslims who must now confront the implications for their faith of al-Qaida's fundamentalist challenge. But in few places could it have been more individually wrenching than

I. R. Benedict, The Chrysanthemum and the Sword: Patterns of Japanese Culture (I946), 24.

2. J. Nathan, 'Translator's Note', in K. Oë, A Personal Matter (I968), viii. For a moving depiction of a child's life at the time of Japan's surrender, see K. Oë, 'The Day the Emperor Spoke in a Human Voice', New York Times, 7 May I995, I03. 
in Japan, a fact that makes Japanese intellectuals of this period so fascinating, and makes their literature, which has tried to describe and plumb the experience, such haunting human documents of remarkable intensity and brilliance.

Judge Oda survived the experience and, ever since, he has presented a serene persona to the world around him. One can only struggle to imagine the trauma he may have suffered as he, with all the others in his generation, went through the process of the disintegration and reconstruction of their inner world and the ways in which that process might relate to the remarkably consistent jurisprudence to be found in the judicial oeuvre of Shigeru Oda.

Given his centrality in international decision making, Judge Oda's inner life will remain a subject for further inquiry, but his qualities are so distinct that one can easily sketch something of his personality merely by observing his behaviour and by reading his judicial opinions.

As an individual, Judge Oda is famous for his extraordinary self-control in personal comportment: who has ever seen him angry, indeed less than perfectly courteous and dignified? Yet Judge Oda is not aloof or compulsively private. He is open and reflective.

As a judge he is a study in independence. His resolution is legendary. At the ICJ, he has produced an unmatched number of dissents and separate opinions, some differing only slightly from the majority. In none of them was he joined by another member of the Court. Yet the dissents do not reveal a 'wrecker', a person who is at all 'anti-institutional', as some dissents, unfortunately, sometimes do. Indeed, in reading through the corpus of Judge Oda's work, one is struck by the number of cases, especially in the latter part of his career, in which Judge Oda expresses serious doubts about the core issue of the majority conception of the law or the facts as narrated in the opinion and yet supports the majority.

Judge Oda is also known for his distinctive ex cathedra style: the extraordinarily detailed and systematic exposition of every step in the logical process, as if the writer-craftsman were unwilling to allow himself to make a leap or to take anything for granted. It is a demand for the most explicit rationality and an extraordinary concern and respect for the political and legal commitments actually made and discoverable. Judge Oda does not dig into texts and legislative histories. He excavates them.

Judge Oda offers a disciplined and realistic vision of policy. Judge Oda's positions, for example, his commitment to equidistance in maritime boundary delimitation, are neither impractical nor impracticable. Quite to the contrary - equidistance may be more practical than equitable principles!

Just as Judge Oda labours to find the legal rule that correctly fits each set of facts, he also disciplines his opinions, writing no more than necessary to address the problem at hand. He has written short opinions - one of his later concurrences is only two sentences, and the longer opinions owe their length to the complexity of the problem, which Judge Oda acknowledges and addresses explicitly. Future 
generations will argue over which of his opinions are more persuasive or even correct, but all will agree that no opinion is wordy or windy.

Of Judge Oda's remarkable intellectual independence and strength of will much could be said, but one telling example, particularly close to my own experience, will suffice. Although Judge Oda studied with Myres McDougal for three years and won his close and lifelong friendship, he was one of the few students who largely resisted the influence of McDougal, who, as many in this room know, was a magnetic and overpowering personality. Instead, Oda selected and incorporated only those concepts, techniques, and linguistic components from the master's opus that served his own purposes. His doctoral dissertation, 'The Riches of the Sea and International Law', which conceives of the oceans in classic McDougal fashion as a multi-purpose resource, proceeds in a manner that is distinctively not McDougal. In a charming tribute to his teacher in a book he dedicated to him in I977, Judge Oda wrote that without Professor McDougal's 'kindness and friendship over the past quarter of a century, I could not have carried out my research in international law, although I have become somewhat heretical'. I would not call it heretical and do not believe that Professor McDougal would have. It shows the influence of New Haven, but it is different and distinctively Judge Oda. Incidentally, I know of no other instance in which Professor McDougal accepted a non-McDougal dissertation, yet took such pride in his student.

\section{JURISPRUDENCE}

Students of the judicial process appreciate that while all decision is concerned with the future, much of judging turns on certain 'givens', inherited factors, such as past agreements and past decisions. Theories of interpretation are, in effect, philosophies of how one relates to the 'givens' of the law and can provide an important insight into the values and methods of a judge. Judge Oda has a clear and distinctive theory of judicial interpretation, compiled from what may be a unique set of influences. His legal formation began at the 'Japanese School of International Law', and this was later tested and transformed by his exposure to the policy sciences approach at Yale. The method shaped by Professors Yokota and Taoka, powerful influences in Japanese jurisprudence at the time the young Oda was a student, emphasized, on the one hand, a Kelsenian normativity and, on the other, the social function or role and the political origin of particular rules. In contrast, Myres McDougal's theory focused on the decision maker and his or her tasks, and sought to equip the decision maker with a set of intellectual tools that would facilitate the performance of those tasks: tools for scrutinizing the self, the ultimate instrument of perception and evaluation, for organizing relevant data in the environment, for identifying and clarifying the policies at stake and, finally, procedures for actually making choices. With respect to the specific task of interpretation, McDougal and his associates ransacked the social science literature for methods for determining the genuine shared expectations of the parties; methods for supplementing them when unanticipated contingencies arose; and methods for tempering and policing expectations that ran against critical community policies. 
Judge Oda appears to have drawn from both of these sources. But he has fashioned his own distinct interpretive method, which has manifested itself most consistently in his approach to the recurring problem of international jurisdiction. Judge Oda's decisions reflect his lifelong conviction that the ICJ must not legislate, and that his leeway in decision making is confined by certain limits inherent in the role of the international judge. Some of Judge Oda's colleagues on the Court and many commentators disagree. In domestic courts, and certainly in the United States, contingent lawmaking competences are accepted as legitimate, if not mandatory, functions of the courts concerned; the quality of the work of the courts engaged in this function is, in large part, judged by the quality of its legislative creativity. However, these various courts operate in domestic political contexts in which this contingent judicial lawmaking is accepted. The ICJ, by contrast, requires an explicit authorization to engage in decision ex aequo et bono. It seems clear that the Statute was not intended to bestow a general power of equitable decision.

Sir Robert Jennings has said:

Ad hoc tribunals can settle particular disputes; but the function of the established 'principal judicial organ of the United Nations' must include not only the settlement of disputes but also the scientific development of general international law... there is therefore nothing strange in the ICJ fulfilling a similar function for the international community.

But, with respect, the Court seems particularly ill structured for a progressive development role. Lawmaking is not a philosophical or scientific exercise. It is quintessentially political, requiring knowledge of the diverse interests and the intensity of demand of the political actors engaged, and then skill in trading support and forming coalitions. The Court cannot do this, and even trying would compromise its judicial character. As for the International Law Commission, which has an explicit 'progressive development' competence, it can engage in this only ad referendum, with the ultimate decision in the hands of the General Assembly or an international diplomatic conference, both explicitly political institutions. Could a court - indeed, any court - render judgments ad referendum? I do not address the moral issue of purporting to make law for communities that have not authorized or agreed to it, which is the moral basis of the demand of national communities for sovereignty.

Judge Oda's jurisprudence reflects a nuanced appreciation of the very special position of the international adjudicator. The conception of the proper judicial role that emerges from the corpus of Judge Oda's decisions is neither general 'progressive development' nor the caricature of blind application of 'rules', legislation, or agreements. It is, rather, a conception of a judicial role, restricted like any other, with limitations that are accepted and honoured by the role player. Within this role, rules are properly seen as communications carrying relevant and authoritative policy information that must be shaped in the idiosyncratic texture of each controversy, to provide a decision that best approximates the minimum order and larger policy objectives of the community. Make no mistake: this is no easy task. The constant possibility of infiltration, whether in factual characterization or legal specification, of personal preferences and prejudices, some operating at levels of consciousness 
so deep that the judge may be unaware of them, greatly complicate the judge's job. Hence Socrates' injunction, 'know thyself', is as fundamental and constant a requirement for the judge as it is for the philosopher. One thinks, in this regard, of Judge Oda's reflection on himself, one of the very few in his entire corpus of work, in Nuclear Tests (New Zealand v. France). He voted with the Court to dismiss the request to reopen the case but added,

as the Member of the Court from the only country which has suffered the devastating effects of nuclear weapons, I feel bound to express my personal hope that no further tests of any kind of nuclear weapons will be carried out under any circumstances.

To be sure, the judicial function involves 'supplementing and policing' the application of inherited law, ${ }^{3}$ which becomes particularly urgent in periods of rapid transition. This is not judicial activism, but an appropriate discharge of the judicial function. It is quite distinct from an active lawmaking role that deems itself entitled to ignore expressions of authoritative policy and assume a competence to determine itself, case by case and 'progressively', what the law should be. That is a conception which Judge Oda has steadfastly resisted.

While several of the majority's initiatives have won praise in some quarters, they have, in the view of others, led the Court into unsuccessful initiatives in international constitutive change. For a period of time, the Court seemed to be elaborating a theory of jurisdiction no longer based on consent. Judge Oda steadfastly resisted this initiative and the Court has essentially returned to his view. The majority's initiatives have also led to the Court's assumption, especially in the area of maritime boundary delimitation, that it is entitled to change the law on a case-by-case basis. Here again, Judge Oda's work is marked by a consistent and detailed examination of existing prescriptions, on the basis of which he tries to fashion the appropriate legal response. Indeed, in many cases in which the ICJ arguably had a substantive impact on international law, Judge Oda has raised a voice of reservation and opposition.

In my view, Judge Oda is right. If the Court reaches for jurisdiction in cases in which there is no consent or tries to engage in legislative exercises without authorization, it puts itself in an awkward position, for a far-reaching judicial lawmaking role requires subterfuge. Article 38 of the Statute is clear, so the Court cannot say:

Formula $\mathrm{A}$ is the law, but we are now putting on our judicial-legislative hats and are going to decide on the basis of formula B, in the exercise of our competence to engage in discretionary 'progressive development'.

In the pretense that formula B is the law, the Court will have to engage in legal legerdemain that will confuse the community as to the methods by which law is to be inferred, will undermine confidence in legal expectations, and will undermine the confidence of others in itself. All of this will have proliferating consequences for the international legal system. Beyond the erosion of stability of expectation, these lawmaking initiatives often have high institutional costs. States are not obliged to turn to the Court for the resolution of their disputes. When they do, their legal

3. M. S. McDougal et al., The Interpretation of International Agreements and World Public Order (I994). 
advisers have presumably studied the relevant parts of international law and enter the Court with some confidence that it will be applied. To have the Court ad hoc 'progressively develop' new norms with retroactive effect will hardly encourage responsible legal advisers to refer cases to the Court.

\section{INFLUENCE}

Judge Oda's personal judicial oeuvre is the largest in the history of the PCIJ and the ICJ. It is theoretically consistent and provides a picture window on the jurisprudence and intellectual modus operandi of its creator. But it is comprised of dissents and of separate opinions that sometimes read like dissents. It has often been a minority view. The judges who have the most manifest influence on any court will be those who write the majority opinion (which of course appears anonymously in the ICJ's practice) or those who, in cameral deliberations, had the greatest influence on shaping the judgment. The author of the separate opinion, whether concurring or dissenting, in effect acknowledges that the position he or she espoused was not accepted by the majority. But do not minimize the contribution of the dissenting opinion. Justice Brennan of the United States Supreme Court said that 'The dissent ... safeguards the integrity of the judicial decision-making process by keeping the majority accountable for the rationale and consequences of its decision.' Justice Frankfurter said that 'Dissent is essential to an effective judiciary in a democratic society.' Charles Evans Hughes, who sat on the PCIJ until he was recalled to become Chief Justice of the United States Supreme Court, said famously that 'A dissent in a court of last resort is an appeal to the brooding spirit of the law, to the intelligence of a future day.'

\section{LEGACY}

I have said enough to show why Judge Oda is an international 'living treasure' and why he himself and his contribution to international law through his scholarship and his service as a judge will continue, like great art, to be studied and to influence us. It is scholarship, but more than scholarship. It is, ultimately, his steadfast custodianship of what he called in his Declaration in Application of the Convention on the Prevention and Punishment of the Crime of Genocide (Bosnia and Herzegovina $v$. Yugoslavia) 'the legal conscience'. 
Reproduced with permission of the copyright owner. Further reproduction prohibited without permission. 